\title{
Pengaruh Motivasi Terhadap Produktivitas Kerja (Studi Pada Karyawan Bank Syariah Mandiri Palu)
}

\author{
Nurwinda Nurwinda ${ }^{1 *}$, Malkan Malkan ${ }^{2}$, Ubay Harun, Dede Arseyani Pratamasyari ${ }^{4}$ \\ ${ }^{1}$ Jurusan Perbankan, Fakultas Ekonomi dan Bisnis Islam, IAIN Palu \\ ${ }^{2}$ Jurusan Perbankan, Fakultas Ekonomi dan Bisnis Islam, IAIN Palu \\ ${ }^{3}$ Jurusan Perbankan, Fakultas Ekonomi dan Bisnis Islam, IAIN Palu \\ ${ }^{4}$ Jurusan Perbankan, Fakultas Ekonomi dan Bisnis Islam, IAIN Palu
}

ABSTRAK

Tulisan ini membahas pengaruh motivasi terhadap produktivitas kerja pada karyawan Bank Syariah Mandiri Palu. Penelitian ini dilakukan dengan menggunakan metode kuantitatif. Jumlah responden penelitian ini adalah 38 orang yang merupakan karyawan Bank Mandiri Syariah Palu. Sampel ini merupakan sampel populasi karena seluruh karyawan dijadikan sampel penelitian ini kemudian dibagikan kuesiner dengan skala Likert 5. Hasil penelitian menunjukkan bahwa tanggapan responden terhadap penilaian motivasi menunjukkan nilai bobot rata-rata sebesar 160. Berdasarkan rentang klasifikasi termasuk dalam kategori sangat baik. Hasil ini menandakan bahwa secara keseluruhan motivasi karyawan pada Bank Syariah Mandiri Area Palu sangat baik. Hasil tanggapan responden terhadap penilaian produktivitas kerja menunjukkan nilai bobot rata-rata sebesar 150. Berdasarkan rentang klasifikasi termasuk kategori baik. Hasil ini berartibahwa secara keseluruhan produktivitas kerja karyawan pada Bank Syariah Mandiri Area Palu sudah baik namun dimensi sikap mental memiliki nilai bobot di bawah bobot rata-rata variabel produktivitas kerja.
INFORMASI

ARTIKEL

Katakunci:

Motivasi Kerja, Produktivitas Kerja, Karyawan, Bank Mandiri Syariah. 


\section{PENDAHULUAN}

PSDI, ${ }^{1}$ atau dalam terminologi lama disebut Manajemen Sumber Daya Manusia mengenal adanya beberapa pendekatan, yang implikasinya adalah perlakuan terhadap para karyawan. Misalnya pendekatan manajemen yang beranggapan bahwa keberadaan SDI adalah untuk melayani para manajer dan karyawan melalui keahliannya. Pada akhirnya kinerja dan kesejahteraan setiap pekerja adalah tanggung jawab bersama (dual-responsibility) dari atasan langsung pekerja dan bagian SDI. Kemudian ada pula pendekatan SDM yang pada intinya beranggapan bahwa organisasi akan tumbuh hanya melalui perhatian yang diberikan terhadap kebutuhan karyawan, sehingga kata kuncinya adalah kebutuhan karyawan. ${ }^{2}$

Pentingnya pengelolaan terhadap sumber daya manusia (SDM) disebabkan karena faktor manusia sebagai pelaku utama dalam setiap kegiatan operasional suatu perusahaan. ${ }^{3}$ Sumber daya manusia (SDM) adalah faktor sentral dalam suatu organisasi

\footnotetext{
${ }^{1}$ Pengelolaan Sumber Daya Insani

${ }^{2}$ Jusmaliani, Pengelolaan Sumber Daya Insani,(Jakarta: PT. Bumi Aksara 2011), 8.

${ }^{3}$ Nur Ainal, Idayanti, Fauziah Umar. "Pengaruh Masa Kerja, Pelatihan, dan Motivasi Terhadap Produktivitas Kerja Karyawan Pada PT. Bank SULSELBAR Cabang Utama Makassar". Vol $1 \quad$ No.1 (April 2018) http://feb.unhas.ac.id/jurnal/index.php/hjabe/article/v iew/32 Diakses 27 Mei 2019.
}

seperti perbankan ${ }^{4}$. Apapun bentuk serta tujuannya, organisasi dibuat berdasarkan berbagai visi untuk kepentingan manusia. Dalam pelaksanaan misinya dikelola dan diatur oleh manusia sebagai sumber daya yang strategis dalam kegiatan institusi maupun organisasi. Tanpa adanya manusia dalam suatu perusahaan, tidak akan mungkin perusahaan tersebut dapat berkembang dan maju sesuai dengan yang diharapkan. Keberhasilan dalam mencapai tujuan perusahaan sangat ditentukan oleh kinerja karyawannya. Seperti yang diungkapkan oleh Veithzal Rivai bahwa "Kinerja karyawan merupakan suatu hal yang sangat penting dalam upaya perusahaan untuk mencapai tujuannya." ${ }^{\circ}$

Faktor sumber daya manusia ini merupakan elemen penting yang harus diperhatikan perusahaan, dimana terjadinya persaingan atau kompetisi yang sangat berbeda. Hal ini memaksa perusahaan untuk bekerja dengan lebih efisien, efektif dan produktif. Sebab dalam pencapaian tujuan

\footnotetext{
${ }^{4}$ Nurdin, N., \& Yusuf, K. (2020).

Knowledge management lifecycle in Islamic bank: the case of syariah banks in Indonesia. International Journal of Knowledge Management Studies, 11(1), 59-80. doi: 10.1504/ijkms.2020.105073

${ }^{5}$ Hari Mulyadi."Pengaruh Motivasi dan Kompetensi Kerja Terhadap Produktivitas Kerja Karyawan pada PT. Galamedia Bandung Perkasa" $\begin{array}{llllll}\text { vol. } & 9 & \text { No. } & 7 & \text { (Juli } & \text { 2010) }\end{array}$ https//ejournal.upi.edu/index.php/manajerial/article/vi ew/1807, Diakses 21 Oktober 2019.
} 
yang diinginkan bukan hanya tergantung pada keunggulan teknologi, operasi yang tersedia sarana dan prasarana yang dimiliki, melainkan juga tergantung dari aspek sumber daya manusianya. Terutama bila mengingat bahwa era perdagangan bebas akan segera dimulai, dimana iklim kompetisi yang dihadapi akan sangat berbeda. Jadi manusia dapat dipandang sebagai faktor penentu karena ditangan manusialah segala inovasi akan direalisir dalam upaya mewujudkan tujuan perusahaan. ${ }^{6}$

Seperti yang telah dijelaskan, bahwa sarana penting dalam mengatur sumber daya manusia dalam suatu instansi adalah melalui karyawan $^{7}$. Orang yang bekerja di suatu instansi dan setiap bulannya mendapatkan gaji disebut dengan karyawan. Kemudian menurut Hasibuan, orang yang menjual jasa dan mendapatkan kompensasi, dimana orang tersebut terikat dan wajib melaksanakan pekerjaan yang telah diberikan serta berhak mendapatkan gaji sesuai perjanjian yang

\footnotetext{
${ }^{6}$ Ibriati Kartika AlimuddinPengaruhMotivasiTerhadapProduktivitasK erjaKaryawanPada PT. Telkom Indonesia, Cabang Makassar,

http://repository.unhas.ac.id/bitstream/handle/

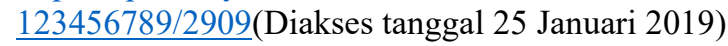

${ }^{7}$ Nurdin, N., Pettalongi, S. S., \& Yusuf, K.
} (2018, 27-28 Sept. 2018). Knowledge Management Model in Syariah Banking. Paper presented at the 2018 5th International Conference on Information Technology, Computer, and Electrical Engineering (ICITACEE) telah disepakati. Maka orang tersebut dapat dikatakan sebagai karyawan. ${ }^{8}$

Karyawan merupakan asset utama organisasi dan mempunyai peran yang strategis didalam organisasi yaitu sebagai pemikir, perencana dan pengendali aktivitas organisasi. Maka dari itu, karyawan memerlukan motivasi untuk bekerja lebih rajin.

Melihat pentingnya kedudukan karyawan dalam organisasi, maka karyawan diperlukan perhatian lebih serius terhadap tugas yang dikerjakan sehingga tujuan organisasi tercapai. Dengan motivasi kerja yang tinggi, karyawan akan bekerja lebih giat dalam melaksanakan pekerjaannya serta membentuk semangat kerjanya. Bila seseorang termotivasi, ia akan berusaha sekuat tenaga untuk mewujudkan apa yang diinginkannya, namun belum tentu akan menghasilkan produktivitas yang diharapkan apabila perusahaan tidak menyalurkannya ke arah yang dikehendaki perusahaan, maka dari itu perusahaan mengarahkannya ke tujuan perusahaan agar produktivitas kerja karyawan mengalami peningkatan secara baik. $^{9}$

Dalam hal ini, motivasi merupakan hal yang berperan penting dalam meningkatkan suatu aktivitas kerja, karena

${ }^{8}$ Malayu S.P. Hasibuan,Manajemen Sumber Daya Manusia,(Jakarta: Bumi Aksara 2014), 12.

${ }^{9}$ Ibid, 13 
motivasi merupakan kekuatan pendorong yang akan mewujudkan perilaku. Motivasi secara sederhana adalah faktor-faktor yang mendorong seseorang untuk berperilaku tertentu ke arah tujuan yang akan dicapainya.

Motivasi sebagai kemauan untuk meningkatkan upaya ke arah pencapaian tujuan organisasi dengan syarat hasil upaya tadi akan memuaskan sebagian kebutuhan individu. Tujuan bermula dari adanya kebutuhan atau keinginan ini dapatdijadikan sebagai pembangkit motivasi. Kebutuhan atau keinginan yang terkandung pada diri orang tersebut adalah bagaimana dapat mewujudkan tujuannya. ${ }^{10}$

Motivasi berasal dari kata latin "Movere" yang berarti "Dorongan atau Daya Penggerak". Motivasi ini hanya diberikan kepada manusia, khususnya kepada bawahan atau pengikut. Motivasi mempersoalkan bagaimana caraya mendorong gairah kerja bawahan, agar mereka mau bekerja dengan memberikan semua kemampuan dan keterampilannya untuk mewujudkan tujuan perusahaan. Motivasi penting karena dengan motivasi ini diharapkan setap individu karyawan mau bekerja keras dan antusias untuk mencapai produktivitas kerja yang tinggi. ${ }^{11}$

\footnotetext{
${ }^{10}$ Jusmaliani, Pengelolaan Sumber Daya Insani, (Jakarta: PT Bumi Aksara, 2011), 80.

${ }^{11}$ Malayu S.P. Hasibuan, Organisasi dan Motivasi(Jakarta: PT. Bumi Aksara, 2014), 93.
}

Dilihat dari pengertian motivasi sendiri, bisa kita lihat motivasi merupakan hal yang sangat penting untuk diperhatikan oleh pihak manajemen bila mereka menginginkan setiap karyawan dapat memberikan kontribusi positif terhadap pencapaian tujuan perusahaan. Karena dengan motivasi, seorang karyawan akan memiliki semangat yang tinggi dalam melaksanakan tugas yang dibebankan kepadanya. Tanpa motivasi, seorang karyawan tidak dapat memenuhi tugasnya sesuai standar atau bahkan melampaui standar karena apa yang menjadi motif dan motivasinya dalam bekerja tidak terpenuhi. Sekalipun seorang karyawan memiliki kemampuan operasional yang baik bila tidak memiliki motivasi dalam bekerja, hasil akhir dari pekerjaannya tidak akan memuaskan.

Produktivitas kerja pun akan terwujud jika para karyawan mempunyai kemampuan dalam menyelesaikan pekerjaan atau tugas yang menjadi tanggung jawabnya masing-masing. Oleh karena itu pimpinan harus dapat memberikan suatu dorongan atau motivasi pada karyawan. Semakin termotivasi karyawan dalam melakukan pekerjaan maka produktivitas kerja karyawan tersebut tinggi. Sebaliknya jika karyawan tidak termotivasi dalam suatu 
pekerjaan maka produktivitas kinerja karyawan rendah. ${ }^{12}$

Bank Syariah Mandiri Area adalah sebuah perusahaan yang bergerak di bidang keuangan dimana kegiatannya menghimpun dana dari masyarakat secara langsung dan memberikan jasa keuangan kepada masyarakat luas. Berdasarkan UU RI No. 10 tahun 1998 tentang perbankan, pengertian bank adalah badan usaha yang menghimpundana dari masyarakat dalam bentuk simpanan dan menyalurkannya kembali kepada masyarakat dalam bentuk simpanan dan menyalurkannya kembali kepada masyarakat dalam bentuk kredit dan atau bentuk-bentuk lainnya dalam rangka meningkatkan tarat hidup rakyat banyak ${ }^{13}$. Melihat pentingnya peran bank, tentunya menuntut setiap pekerja di dalamnya untuk senantiasa produktif dalam pelayanannya sebagai intermediary.

Berdasarkan observsi awal, Bank Syariah Mandiri Area mempunyai aktivitas kesibukan yang lebih tinggi dibandingkan Bank Syariah Mandiri Cabang. Mengingat bahwa Bank Syariah Mandiri Area bertempat di lokasi yang termasuk startegis

\footnotetext{
${ }^{12}$ Ibriati Kartika, Pengaruh Motivasi Terhadap Produktivitas kerja Karyawan pada PT. Telkom Indonesia Cabang Makassar,http://repository.unhas.ac.id/bitstream/hand

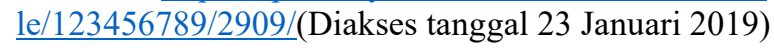

${ }^{13}$ Mohammad Rizal, Perbankan Syariah, (Malang: Empatdua Media, 2016) hal 5.
}

yaitu di tengah kota sehingga banyak nasabah lebih memilih bertransaksi di kantor Area. Alasan itu yang membuat Bank Syariah Mandiri Area dalam hal pelayanan dikatakan cukup tinggi. Selain alasan itu, Bank Syariah Mandiri Area juga mengurusi cabang-cabang yang dibawahi. ${ }^{14}$

\section{TINJAUAN PUSTAKA}

\section{$2.1 \quad$ Pengertian motivasi}

Setiap orang dalam melakukan tindakan tertentu pasti didorong oleh adanya motif tertentu. Motivasi biasanya timbul karena adanya kebutuhan yang belum terpenuhi, tujuan yang ingin dicapai, atau karena adanya harapan yang diinginkan. motivasi kerja merupakan kombinasi kekuatan psikologis yang kompleks dalam diri masing-masing orang. Setiap individu mempunyai motivasi sendiri yang mungkin berbeda-beda. Istilah motivasi dapat didefinisikan sebagai keadaan internal individu yang melahirkan kekuatan, kegairahan dan dinamika, serta mengarahkan tingkah laku pada tujuan. Dalam pengertian lain, motivasi merupakan istilah yang dipergunakan untuk menunjuk sejumlah dorongan, keinginan, kebutuhan, dan kekuatan. $^{15}$

\footnotetext{
${ }^{14}$ Observasi Pra Penelitian (Wawancara
} dengan Pak Syahrullah, Petugas Bagian Gadai tanggal 15 Mei 2019)

${ }^{15}$ Abdul Hamid Mursi, SDM Yang Produktif, Terj. Moh Nurhakim, (Jakarta: Gema Insani Pres, 1999), 91. 
Menurut Kamus Lengkap Bahasa Indonesia Modern karangan Muhammad Ali, Motif diartikan : dorongan tindakan seseorang ; dasar pikiran dan pendapat ; sesuatu yang menjadi pokok. Sehingga dari motiv tersebut, dapat diturunkan pengertian motivasi sebagai sesuatu yang pokok yang menjadi dorongan seseorang untuk bekerja. ${ }^{16}$

Peranan manusia dalam mencapai tujuan, sangat penting dalam mencapai tujuan organisasi. Untuk menggerakkan manusia agar sesuai dengan yang dikehendaki organisasi, maka haruslah dipahami motivasi manusia bekerja pada suatu organisasi, karena motivasi inilah yang menentukan perilaku orang-orang untuk bekerja atau dengan kata lain perilaku merupakan cerminan yang paling sederhana dari motivasi. Adapun beberapa definisi dari motivasi dari beberapa ahli sebagai berikut :

Motivasi adalah keinginan untuk bertindak. Setiap orang dapat termotivasi oleh beberapa kekuatan yang berbeda. Di pekerjaan, kita perlu memengaruhi bawahan untuk menyelaraskan motivasinya dengan kebutuhan organisasi. ${ }^{17}$

Motivasi merupakan proses psikologis yang membangkitkan perilaku

\footnotetext{
${ }^{16}$ Ishak Arep dan Hendri Tanjung, Manajemen Sumber Daya Manusia(Jakarta: Universitas Trisakti, 2003), 217.

${ }^{17}$ Wibowo, Manajemen Kinerja Edisi Ketiga(Jakarta: RajaGrafindo Persada, 2007), 378.
}

pada pencapaian tujuan atau goal-directed behavior (Robert Kreitner dan Angelo Kinicki). Manager perlu memahami proses psikologis ini apabila mereka ingin berhasil membina pekerja menuju pada penyelesaian sasaran organisasi. ${ }^{18}$

Motivasi adalah pemberian daya penggerak yang menciptakan kegairahan kerja seseorang, agar mereka mau bekerja sama, bekerja efektif dan terintegrasi dengan segala daya upayanya untuk mencapai suatu kepuasan. ${ }^{19}$

Motivasi sebagai proses yang memperhitungkan intensitas, arah dan ketekunan usaha individual terhadap pencapaian tujuan. Motivasi pada umumnya berkaitan dengan setiap tujuan,sedangkan tujuan organisasional memfokus pada perilaku yang berkaitan dengan pekerjaan. ${ }^{20}$

Motivasi merupakan unsur penting dalam suatu aktivitas kerja, karena motivasi merupakan kekuatan pendorong yang akan mewujudkan perilaku. Motivasi adalah kejiwaan dan sikap mental manusia yang memberikan energi, mendorong kegiatan atau gerakan yang mengarah dan menyalurkan perilaku kearah mencapai

\footnotetext{
${ }^{18}$ Ibid.

${ }^{19}$ Malayu S.P Hasibuan, Organisasi dan Motivasi Dasar Peningkatan Produktivitas (Jakarta: Bumi Kasara, 2014), 95.

${ }^{20} \mathrm{~A}$. Anwar Mangkunegara, ManajemenSumberDayaManusia Perusahaan, (Bandung: RosdaKarya, 2004), 93.
} 
kebutuhan yang member kepuasan atau mengurangi ketidakseimbangan. ${ }^{21}$

a. Motivasi dalam Perspektif Islam

Teori-teori motivasi yang dikemukakan oleh para ahli sebagaimana dipaparkan di atas, sebagian besar masih bersifat jangka pendek. Artinya, hanya sekedar pemenuhan kebutuhan atau perilaku manusia dalam kehidupannya di dunia. Motivasi tersebut berorientasi kepada reward yang biasanya dapat diukur dengan materi.Di lain pihak, secara syariah Islam, kehidupan manusia tidak dibatasi hanya di dunia saja. Ada kehidupan lain yang lebih penting setelah melewati alam fana ini, yaitu kehidupan di alam akhirat. Gerak aktivitas manusia di dunia ini, haruslah dimotivasi oleh adanya keyakinan atas kehidupan akhirat ini.

Dalam khazanah ilmu pengetahuan Islam, ada definisi yang dikemukakan oleh pakar ilmu jiwa, bahwa motivasi adalah dorongan atau keinginan psikologis atau kejiwaan yang ada pada diri seseorang, keinginan ini mempengaruhi perilaku pada keadaan khusus untuk memenuhi apa yang dihajatkannya, keinginan ini berupa desakdesakan atau dorong-dorongan atau kecondongan hati untuk melakukan sesuatu.
Terminologi motivasi dalam Islam disebut ad daafi' dalam bentuk tunggal, atau ad dawaafi'dalam bentuk jamak. Dalam artikelnya, Al Kaysi menjelaskan bahwa pakar ilmu jiwa membagi motivasi atau keinginan diri menjadi dua bagian, yaitu : 1) dorongan primer, dan 2) dorongan sekunder. Dorongan primer dinamakan juga motivasi atau dorongan dasar atau fitrah atau alamiah. Dorongan primer dapat berupa dorongan rasa lapar atau haus, dalam hal ini manusia tidak perlu mengusahakan untuk mendapatkan rasa ini. Sedangkan dalam dorongan sekunder adalah motivasi atau dorongan yang harus diusahakan. Dalam hal dorongan ini, manusia berbeda antara satu dengan lainnya. ${ }^{22}$

Untuk mencari teoti motivasi bersumberkan pemikiran Islam sangatlah sulit, termasuk bagi kalangan cendekiawan Muslim. Kalaupun ada, hal itu hanyalah tafsiran llmiah terhadap beberapa ayat AlQur'an atau Hadis Nabi yang direlevansikan terhadap teori-teori motivasi yang telah ada.

Untuk mengetahui motivasi kerja dalam Islam, kita perlu memahami terlebih dahulu fungsi dan kedudukan bekerja. Mencari nafkah dalam Islam adalah sebuah kewajiban. Islam adalah agama fitrah, yang sesuai dengan kebutuhan manusia,

\footnotetext{
${ }^{22}$ Maryani, “Motivasi dalam perspektif Islam”,http://journal.staimaarif jambi.ac.id/index. php./annadhah/article/view/42/110a (Diakses tanggal November 2019)
} 
diantaranya kebutuhan fisik, Dan salah satu cara memenuhi kebutuhan fisik itu ialah dengan bekerja.

Motivasi dalam Islam itu adalah untuk mencari nafkah yang merupakan bagiandari ibadah. Motivasi kerja dalm Islam bukanlah untuk megejar hidup hedonis, bukan juga untuk status, apa lagi untuk mengejarkekayaan dengan segala cara. Dengan demikian, motivasi kerja dalam Islam, bukan hanya memenuhi nafkah semata tetapi sebagai kewajiban beribadah kepada Allah setelah ibadah fardhu lainnya. Bekerja mencari nafkah adalah hal yang istimewa dalam pandangan Islam.

Dalam Islam, kebutuhan yang ingin dicapai oleh seorang individu haruslah sesuai dengan aturan agama. Menurut Sharafeldin, Islam adalah sebuah budaya yang dibangun atas dasar kepercayaan atau keimanan. Hal tersebut akan tergambar dalam sebuah sistem kepercayaan dan perilaku sosial. Sebagai sebuah bagian, perilaku sosial tersebut akan mengarahkan bagaimana seorang individu bertindak dan berfikir. Dengan begitu untuk memahami apa motivasi dalam sudut pandang agama Islam, hal yang harus dipahami bagaimana psikologi seorang muslim. Ibnu Khaldun menyatakan bahwa Islam mempertimbangkan sebuah hirarki atau tingkatan hati sesorang, bukan hirarki kebutuhan yang mementukan sebuah perilaku. Tingkatan hati manusia tersebutlah yang akan menentukan apakah sebuah kebutuhan terpuaskan yang pada akhirnya akan memotivasi seseorang. SelanjutnyaIbnu Khaldun menyatakan bahwa ada tiga bagian tingkatan hati yaitu ${ }^{23}$ :

1. Ammara(the prone-to-evil psyche) yang mana akan mengarahkan pada perbuatan jahat, dan jika tidak awasi dan dikontrol, akan menyebabkan masuk neraka. Pada level ini, hati ingin dan siap melakukan kejahatan dan menghindari kebaikan. Keadaan hati tersebut akan menyebabkan sesorang tidak mempedulikan lagi kerugian, keadilan, melindungi dirinya dengan kekayaan dan kemewahan, dan perhatian kebutuhan psikologis dan biologis cenderung pada makanan, hubunga biologis, dan sebagainya. Kepuasan yang didapatkan dari kebutuhan tersebut tidak akan dicapai tanpa membahayakan kebutuhan yang lain.

2. Lawama(selfreproaching psyche), yang mana sadar akan kejahatan, menahannya hal tersebut, berdoa dan memohon ampun memohon kepada Allah setelah bertaubat dan berharap mendapatkan keselamatan. Seseorang dengan hati ini mampu menyalahkan diri sendiri atas perilaku

\footnotetext{
${ }^{23}$ Misna Kablina Nur, "Pengaruh Motivasi Kerja dalam Perspektif Islam terhadap Produktivitas Kerja Karyawan Pada PT. TELKOM Makassar, http://repositori.uin-alauddin.ac.id/7641/(Diakses tanggal 10 Mei 2019)
} 
yang telah dibuat, dan berjanji tidak mengulangi perbuatan negatif tersebut. Hati dalam tingkatan ini ada diantara dua dimensi yaitu kebaikan dan yang kejahatan.

3. Ammara, atau berubah menjadi lebih baik ke tingkatan Mutmainna. Tingkatan1. terakhir dari hati adalah Mutmainna (the righteous psyche), adalah level tertinggi dari hati. Hati yang telah mencapai kedamaian dan kepuasaan dimana seseorang pada level ini terjamin penuh, dan mampu menguasai diri dari kesenangan. Menurut Ahmad seorang muslim yang mempunyai hati tingkatan ini akan mempunyai spiritualitas yang tinggi dan memahami hakekat manusia. Kenyaman, individu merasa kesenangan, keamanan, dan keselamatan, dapat tercapai melalui sebuah komitmen bahwa apapun yang dilakukan adalah karena Allah. Pada tingkatan ini, Allah adalah tujuan dari apapun aktivitas yang dilakukan. Hati pada tingkatan ini secara sukarela akan mengarahkan kepada kebaikan dan menghindari keburukan. ${ }^{24}$

Selanjutnya Akh. Muwafik dalam bukunya yang berjudul Bekerja dengan Hati Nurani, mengatakan "Bahwa selama ini, banyak orang bekerja untuk mengajar materi belaka demi kepentingan duniawi, mereka

\footnotetext{
${ }^{24}$ Akh.MuwafikSaleh, BekerjadenganHatiNurani, (Jakarta: Erlangga, 2009),
} 65. tak sedikitpun memerdulikan kepentingan akhirat kelak. Oleh karena itu sudah saatnya para pekerja bekerja dengan motivasi yang dapatmemberikan kepribadian yang baik dan dibenarkan oleh Islam yang harus memenuhi ciri-ciri sebagai berikut" 25 :

\section{Niat Baik dan Benar}

Sebelum seseorang bekerja, harus mengetahui apa niat dan motivasi dalam bekerja, niat inilah yang akan menentukan arah pekerjaan. Jika niat bekerja hanya untuk mendapatkan gaji, maka hanya itulah yang akan didapat. Tetapi jika niat bekerja sekaligus untuk menambah simpanan akhirat, mendapat harta halal, serta menafkahi keluarga, tentu akan mendapatkan sebagaimana yang diniatkan. Takwa dalam Bekerja

Takwa di sini terdapat dua pengertian. Pertama, taat melaksanakan perintah dan menjauhi segala bentuk larangan-Nya. Kedua, sikap tanggung jawab seorang muslim terhadap keimanan yang telah diyakini dan diikrarkannya. Orang yangbertakwa dalam bekerja adalah orang yang mampu bertanggung jawab terhadap segala tugas yang diamanahkan.Orang yang bertakwa atau bertanggung jawab akan selalu menampilkan sikap-sikap positif, untuk itu orang yang bertakwa dalam bekerja

\footnotetext{
${ }^{25}$ Ibid., 66.
} 
akan menampilkan sikap-sikap sebagai berikut $^{26}$ :

1. Bekerja dengan cara terbaik sebagai wujud tanggung jawab terhadap kerja dan tugas yang diamanahkan.

2. Menjauhi segala bentuk kemungkaran untuk dirinya dan orang lain dalam bekerja. Misalnya, tidak malas-malasan, merugikan rekan kerja, dsb.

3. Taat pada aturan.

4. Hanya menginginkan hasil pekerjaan yang baik dan halal.

a. Ikhlas dalam Bekerja

Ikhlas adalah syarat kunci diterimanya amal perbuatan manusia disisi Allah SWT. Suatu kegiatan atau aktivitas termasuk kerja jika dilakukan dengan keikhlasan maka akan mendatangkan rahmat dari Allah SWT. Adapun ciri-ciri orang yang bekerja dengan Ikhlas yaitu ${ }^{27}$ :

1. Bekerja semata-mata mengharap ridha Allah SWT.

2. Bersih dari segala maksud pamrih dan ria.

3. Penuh semangat dalam mengerjakan seluruh tugas pekerjaan.

4. Tidak merasa rendah karena makian atau cercaan sehingga tidak mengurangi semangat dalam bekerja.

Mencari rezeki yang halal dalam agama Islam hukumnya wajib. Ini

\footnotetext{
${ }^{26}$ Ibid., 77.

${ }^{27}$ Ibid., 84.
}

menandakan bagaimana penting mencari rezeki yang halal. Dengan demikian, motivasi kerja dalam Islam bukan hanya memenuhi nafkah semata tetapi sebagai kewajiban ibadah fardlu lainnya. Islam sangat layak untuk dipilih sebagai jalan hidup (way of life). Islam tidak hanya berbicara tentang moralitas akhlak, tetapi juga memberikan peletakan dasar tentang konsep-konsep membangun kehidupan dan peradaban tinggi. ${ }^{28}$

d. Faktor-Faktor yang Mempengaruhi Motivasi

Motivasi seseorang dapat dipengaruhi oleh dua faktor yaitu ${ }^{29}$ :

\section{Faktor Internal}

Faktor yang berasal dari dalam diri individu, terdiri atas:

a. Persepsi individu mengenai diri sendiri, seseorang termotivasi atau tidak untukmelakukan sesuatu banyak tergantung pada proses kongnitif berupa persepsi.Persepsi seseorang tentang dirinya sendiri akan mendorong dan mengarahkanperilaku seseorang untuk bertindak.

\footnotetext{
${ }^{28}$ Alaik Allama, "Pengaruh Motivasi Kerja Islam dan Budaya Kerja Islam Terhadap Produktivitas Kerja Karyawan BAITUL MAL WAT $\begin{array}{llll}\text { TAMWIL (BMT) DI } & \text { KUDUS, }\end{array}$ http://library.walisongo.ac.id/digilib/files/disk1/136/jt ptiain--alaikallam(Diakse tanggal 10 Mei 2019)

${ }^{29}$ Eka Suhartini, Motivasi, Kepuasan Kerja Dan Kinerja, (Jakarta: Alauddin University Press, 2013), 31.
} 
b. Harga diri dan prestasi, faktor ini mendorong atau mengarahkan individu(memotivasi) untuk berusaha agar menjadi pribadi yang mandiri, kuat, danmemperoleh kebebasan serta mendapatkan status tertentu dalam lingkunganmasyarakat, serta dapat mendorong individu untuk berprestasi.

c. Harapan, adanya harapan-harapan akan masa depan. Harapan ini merupakaninformasi objektif dari lingkungan yang mempengaruhi sikap dan perasaansubjektif seseorang. Harapan merupakan tujuan dari perilaku.

d. Kebutuhan, manusia dimotivasi oleh kebutuhan untuk menjadikan dirinya sendiriyang berfungsi secara penuh, sehingga mampu meraih potensinya secara total.Kebutuhan akan mendorong dan mengarahkan seseorang untuk mencari ataumenghindari, mengarahkan dan memberi respon terhadap tekanan yangdialaminya.

e. Kepuasan kerja, lebih merupakan suatu dorongan efektif yang muncul dalam diriindividu untuk mencapai goal atau tujuan yang diinginkan dari suatu perilaku.

2. Faktor Eksternal

Faktor yang berasal dari luar diri individu, terdiri $\operatorname{atas}^{30}$ :

\footnotetext{
${ }^{30}$ Ibid, 33.
}

a. Jenis dan sifat karyawan, dorongan untuk bekerja pada jenis dan sifatkaryawanan tertentu sesuai dengan objek karyawanan yang tersedia akanmengarahkan individu untuk menentukan sikap atau pilihan karyawanan yangakan ditekuni. Kondisi ini juga dapat dipengaruhi oleh sejauh mana nilai imbalanyang dimiliki oleh objek karyawanan dimaksud.

b. Kelompok kerja dimana individu bergabung, kelompok kerja atau organisasitempat dimana individu bergabung dapat mendorong atau mengarahkan perilakuindividu dalam mencapai suatu tujuan perilaku tertentu.

c. Situasi lingkungan pada umumnya, setiap individu terdorong untuk berhubungandengan rasa mampunya dalam melakukan interaksi secara efektif denganlingkungannya.

d. Sistem imbalan yang diterima, imbalan merupakan karakteristik atau kualitasdari objek pemuas yang dibutuhkan oleh seseorang dapat mempengaruhimotivasi atau dapat mengubah arah tingkah laku dari satu objek ke objek lainyang mempunyai nilai imbalan yang lebih besar. Sistem pemberian imbalandapat mendorong individu untuk berperilaku dalam mencapai tujuan, perilakudipandang sebagai tujuan, sehingga ketika tujuan tercapai maka akan timbul imbalan. 


\subsection{Produktifitas Kerja}

\section{a. Pengertian produktivitas}

Setiap organisasi baik berbentuk perusahaan maupun lainnya akan berupaya agar para anggotanya atau pekerja yang terlibat dalam kegiatan organisasi dapat memberikan prestasi dalam bentuk produktivitas kerja yang tinggi untuk mewujudkan tujuan yang telah ditetapkan.

Produktivitas kerja karyawan bagi suatu perusahaan sangatlah penting sebagai alat pengukur keberhasilan dalam menjalankan usaha. Karena semakin tinggi produktivitas kerja karyawan dalam perusahaan, berarti laba perusahaan dan produktivitas akan meningkat. Pada dasarnya produktivitas mencangkup sikap mental patriotik yang memandang hari depan secara optimis degan berakar pada keyakinan diri bahwa kehidupan hari ini adalah lebih baik dari hari kemarin dan hari esok adalah lebih baik dari hari ini. ${ }^{31}$

Produktivitas menurut Dewan Produktivitas Nasional mempunyai pengertian sebagai sikap mental yang selalu berpandangan bahwa mutu kehidupan hari ini harus lebih baik dari kemarin dan hari esok lebih baik dari hari ini. ${ }^{32}$

\footnotetext{
${ }^{31}$ Muchdaryah Sinungan, Produktivitas apa dan Bagaimana, (Jakarta: Bumi Aksara 1997), 2.

${ }^{32}$ Husein Umar, Riset Sumber Daya Manusia Dalam Organisasi, (Jakarta: PT. Gramdia Pustaka Utama), 9.
}

Arun Monappa Mirza S. Saiyadain merumuskan produktivitas sebagai berikut: "Productivity is the ratio of a given amount of output to a given amount of input for a spesific period of time (Produktivitas adalah perbandingan jumlah keluaran (output) tertentu dengan jumlah masukan (input) tertentu untuk suatu jangka waktu tertentu). ${ }^{33}$ Senada dengan itu, Sondang P. Siagian berpendapat bahwa produktivitas adalah perbandingan antara hasil suatu pekerjaan dari suatu pekerjaan karyawan dengan pengorbanan yang telah dikeluarkan. Sedangkan Rusli Syarif mengatakan bahwa "definisi produktivitas secara sederhana adalah hubungan antara kualitas yang dihasilkan dengan jumlah kerja yang dilakukan untuk mencapai hasil itu. ${ }^{34}$

Selanjutnya untuk lebih jelas mengenai produktivitas, alat analis yang dikemukakn oleh Rusli Syarif dalam buku Produktivitas, adalah sebagai berikut: (1) jumlah waktu, yaitu adanya penyelesaian suatu pekerjaan yang tepat pada waktunya; (2) mutu, yaitu adanya pencapaian hasil dari pekerjaan yang sesuai dengan targetyang telah ditentukan sebelumnya; efisiensi dan efektivitas, yaitu pengehematan pemakaian sumber daya yang optimal dipakai untuk

\footnotetext{
${ }^{33}$ Moekijat, Manajemen Kepegawaian, (Bandung: Mandar Maju 1989), 191.

${ }^{34}$ Mila Badriyah, Manajemen Sumber Daya
} Manusia (Bandung: Pustaka Setia 2015), 180 
mencapai hasil yang telah ditentukan.

Sumber daya manusia memegang peranan penting dalam proses peningkatan produktivitas karena alat produksi dan teknologi pada hakikatnya merupakan hasil karya manusia.

Pada kesimpulannya, produktivitas kerja diartikan sebagai hasil pengukuran mengenai apa yang telah diperoleh dari apa yang telah diberikan oleh karyawan dalam melaksanakan pekerjaan yang telah dibebankan pada kurun waktu tertentu.Produktivitas melibatlkan peran aktif tenaga kerja untuk menghasilkan hasl maksimal dengan melihat kualitas dan kuantitas pekerjaan mereka.

\subsection{Hipotesis}

Hipotesis berasal dari kata hypo yang berarti dibawah dan thesa yang berarti kebenaran, hipotesis dapat didefinisikan sebagai jawaban sementara yang kebenarannya masih harus diuji. Hipotesis juga merupakan proposisi yang akan diuji keberlakuannya atau merupakan suatu jawaban sementara atas pertanyaan penelitian.

Berdasarkan latar belakang dan masalah yang dikemukakan maka hipotesis yang digunakan dalam penelitian ini adalah :

Ha : Diduga bahwa motivasi berpengaruh terhadap produktivitas kerja (Studi pada Karyawan Bank Syariah Mandiri Area Palu).

\section{METHODOLOGY}

Dalam melakukan penelitian ini penulis menggunakan penelitian kuantitatif. Metode penelitian kuantitatif dapat diartikan sebagai metode penelitian yang berlandaskan pada filsafat positivisme, digunakan untuk meneliti pada populasi atau sampel tertentu, teknik pengambilan sampel pada umumnya dilakukan secara random, pengumpulan data menggunakan instrumen penelitian, analisis data bersifat/statistik dengan tujuan untuk menguji hipotesis yang telah ditetapkan. ${ }^{35}$

Filsafat positifisme memandang realitas/gejalah/fenomena itu dapat diklasifikasikan, relatif tetap, konkrit, teramati, terukur, dan hubungan gejalah bersifat sebab akibat ${ }^{36}$. Penelitian pada umumnya dilakukan pada populasi atau sampel tertentu yang representatif. ${ }^{37}$

Lokasi penelitian di Bank Mandiri Syariah cabang Palu yang terletak di Jalan Penelitian ini berlokasi di Jl. Wolter Wonginsidi No. 133 C Kota Palu, Kecamatan Palu Selatan, Provinsi Sulawesi

${ }^{35}$ Sugiyono, Metode Penelitian Pendidikan Pendekatan Kuantitatif, Kualitatif, dan $R \& D$, (Cet. XX; Bandung: Alfabeta, 2014), hal.14

${ }^{36}$ Nurdin, N. (2017b). To Research Online or

Not to Research Online: Using Internet-Based Research in Islamic Studies Context. Indonesian Journal of Islam and Muslim Societies, 7(1), 31-54.

${ }^{37}$ Nurdin, N. (2017a). Research in Online Space: The Use of Social Media for Research Setting Jurnal Sistem Informasi (Journal of Information System), 13(1), 67-77. 
Tengah. Sampel penelitian ini berjumlah 38 orang.

Data dikumpul melalui survey yang dibagikan kepada jumlah sampel tersebut. Survey menggunakan skala Likert 5. Hasil penelitian kemudian di olah dengan menggunakan SPSS. Hasil survey terlebih dahulu dilakukan uji validitas dan reliabilitas sebelum dilakukan uji f.

\section{HASIL DAN PEMBAHASAN}

\subsection{Demografi Respondent}

Penelitian ini dilakukan pada Nasabah penabung pada Bank BNI Syariah cabang Palu. Data penelitian menggunakan instrument kuesioner yang dibagikan kepada karyawan bank mandiri Syariah cabang Palu sebagai sampel penelitian. Penyebaran kuesioner disebarkan oleh peneliti kepada sampel yang diteliti dengan perincian seperti dalam tabel berikut ini.

Tabel 1. Sebaran Kuesioner

\begin{tabular}{|c|c|c|c|c|}
\hline $\begin{array}{l}\text { Junlal } \\
\text { Siompel }\end{array}$ & $\begin{array}{l}\text { Kusiorer } \\
\text { l Jis:har }\end{array}$ & $\begin{array}{c}\text { Kuisiser } \\
\text { Kambali }\end{array}$ & $\begin{array}{l}\text { Kraisioner } \\
\text { I Miolals }\end{array}$ & Prrasnrase \\
\hline 48 & 48 & 48 & 48 & 101024 \\
\hline
\end{tabular}

Pada bagian metodologi dijelaskan bahwa jumlah sampel yang digunakan dalam penelitian ini adalah 38 orang karyawan Bank Syariah Mandiri Area Palu. Data responden dalam penelitian ini dijelaskan dalam tabel sebagai berikut:
Tabel 2. Responden Berdasarkan Jenis Kelamin

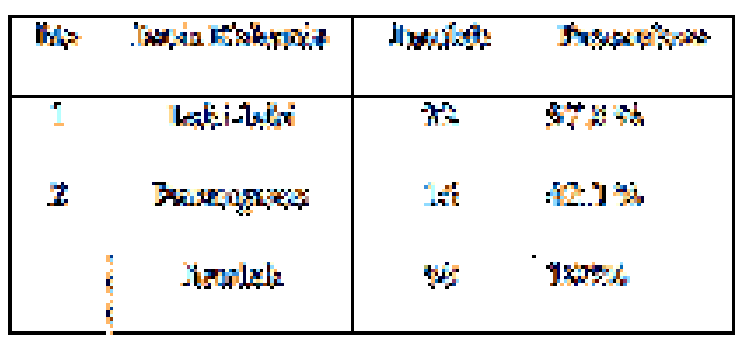

Pada tabel 2 diatas menunjukan bahwa dari 38 orang sampel dalam penelitian ini yang berjenis kelamin laki-laki berjumlah 22 orang $(57,8 \%)$ dan yang berjenis kelamin perempuan 16 orang $(42,1$ \%) sehingga nampak disini bahwa sebagian besar sampel penelitian ini berjenis kelamin laki-laki.

\subsection{Uji Validitas dan Reliabilitas}

Dengan menggunakan instrumen yang valid dan realibel dalam pengumpulan data, maka diharapkan hasil penelitian akan menjadi valid dan realibel. Jadi instrumen valid dan realibel merupakan syarat mutlak untuk mendapatkan hasil penelitian yang valid dan realibel. Hal ini tidak berarti bahwa dengan menggunakan instrumen yang telah teruji validitas dan realibitasnya, otomatis hasil (data) penelitian menjadi valid dan realibel. Hal ini masih akan di pengaruhi oleh kondisi objek yang di teliti, dan kemapuan orang yang menggunakan instrumen untuk mengumpulkan data.

Instrumen yang dinyatakan valid dan realibel adalah; instrumen yang valid, berarti alat ukur yang digunakan untuk mendapatkan data (mengukur) itu valid. 
Valid berarti instrumen tersebut dapat digunakan untuk mengukur apa yang seharusnya diukur. Sedangkan instrumen yang realibel berarti bila digunakan untuk mengukur berkali-kali akan menghasilkan data yang sama.

Uji validitas yaitu mengkorelasikan masing-masing pernyataan dengan jumlah skor untuk masing-masing variabel. Syarat minimum untuk memenuhi syarat adalah apabila $\mathrm{r}=0,3$ jadi apabila korelasi antar butir dengan skor total kurang dari 0,3 maka instrumen tersebut tidak valid. ${ }^{38}$

Tabel 3. Uji Validitas

\begin{tabular}{|c|c|c|c|c|}
\hline \multirow[t]{2}{*}{ Fag shil } & 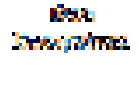 & 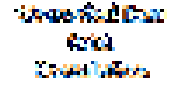 & $\begin{array}{c}\text { lis } \\
\text { zists. }\end{array}$ & $2 a$ \\
\hline & 3 & $7,4 * 9$ & 408 & Tati: \\
\hline \multirow{10}{*}{ 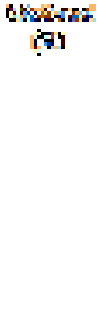 } & $\overline{0}$ & दix:s & t) & Hat: \\
\hline & $y$ & c.Xn & s, ste & Foi \\
\hline & a & 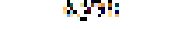 & s.s. & Fon: \\
\hline & $\pi$ & BAs: & $3 \times$ & \% \\
\hline & $\stackrel{\leftrightarrow}{*}$ & tosin: & 830 & i2. \\
\hline & s & F;ex & †,ग & Peta \\
\hline & f & 4\%25 & 4 & Ewaik \\
\hline & 7 & $2,54 !$ & 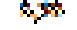 & الفلون \\
\hline & $\therefore$ & 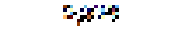 & 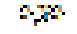 & Tid: \\
\hline & $\because$ & $4: 55$ & $t$ & reth \\
\hline \multirow{22}{*}{ 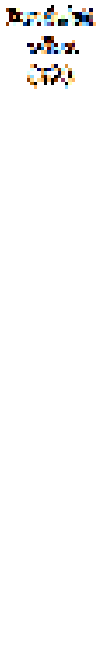 } & 3 & 8,2 & s. & avit \\
\hline & 2 & A. 3 ? & 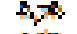 & Sal: \\
\hline & 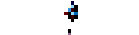 & $c \cdot \vec{x} *$ & $0 \times 0$ & rul: \\
\hline & $\stackrel{4}{*}$ & $1: \frac{1}{4}-5$ & 0 & thes. \\
\hline & $\because$ & 7294 & $6 \geqslant$ & Wat: \\
\hline & 3 & a,sy & 实垓 & "tan: \\
\hline & 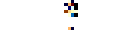 & 4.90 & 4,0 & $\dot{\phi} \alpha$ \\
\hline & $?$ & 0 & a. & $\sin$ \\
\hline & $\because$ & 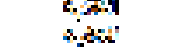 & $\begin{array}{l}4, x< \\
6 x\end{array}$ & कi \\
\hline & $\mathrm{xt}$ & op: : & קצק & $\forall \leqslant$. \\
\hline & 78 & $x$ 전 & $6 x$ & Sith. \\
\hline & is & $5: 3000$ & thto & $28 \theta_{i}$ \\
\hline & s & 4002 & 48 & as: \\
\hline & $\therefore$ & $8 x x^{6}$ & $\Delta, 5$ & s. \\
\hline & $\because$ & $=804$ & $x$ & VA \\
\hline & $\$$ & ves: & $7 \% ?$ & 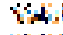 \\
\hline & ab & 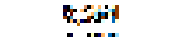 & $t>$ & ist: \\
\hline & 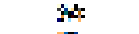 & $5 \times 32$ & st & atui \\
\hline & $\pi$ & 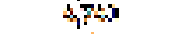 & $2, *$ & $\ddot{w}$ is \\
\hline & 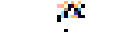 & $5-2 \pi 0$ & 0.30 & "is: \\
\hline & 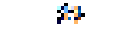 & i: ने, & 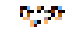 & $V *$ \\
\hline & Fs & r w H & 4 & Jैat \\
\hline
\end{tabular}

Tabel di atas, terlihat bahwa nilai $\mathrm{r}_{\text {hitung }}$ kolom Corrected Item Total

${ }^{38}$ Sugiyono, Metode Penelitian Kuantitatif, Kualitatif dan $R$ an D, 20.
Correlation untuk masing-masing dari ke 3 variabel di atas dinyatakan semua pernyataan valid karena $r_{\text {hitung }}$ lebih besar dan positif dari 0,30 .

Melakukan pengujian ralibilitas dalam penelitian inidigunakan program SPSS (Statistical Packaged For Sosial Siences) versi 16 dimana dala mengukur realibilitas disini menggunakan uji statistik Cronbach's Alpha (a) lebih dari 0,60. Hasil pengujian realibilitas instrumen menggunakan alat bantu oleh statistik SPSS versi 16 for windows dapat diketahui sebagaimana tabel berikut.

Tabel 4. Uji Reliabilitas

\begin{tabular}{|c|c|c|c|}
\hline & Bcitubitity & Cronduck & \\
\hline Variabsl & Cuslficisnz & Aiphisi & Xet:a \\
\hline Wutivas:(X.) & LOItean & 0.883 & Recilibel \\
\hline Irochultivitos & 24 Item & $01,21 \%$ & Realibel \\
\hline
\end{tabular}

Tabel di atas dapat diketahui masingmasing variabel memiliki Cronbach's Alpha (a) lebih dari 0,60 $(a>0,60)$, yang artinya bahwa semua variabel yaitu $\mathrm{X}$ dan $\mathrm{Y}$ adalah reliabel. Dengan demikian pengolahan data dapat dilanjutkan ke jenjang selanjutnya.

\subsection{Analisis Regresi Linier Sederhana \\ Penelitian ini bertujuan ntuk menguji} dan mengetahui besarnya pengaruh motivasi terhadap produktivitas kerja karyawan di Bank Syariah Mandiri Area Palu. Digunakan metode analisis regresi linier sederhana 
dengan menggunakan program SPSS 16.0 Analisis tersebut dapat dilihat sebagai berikut :

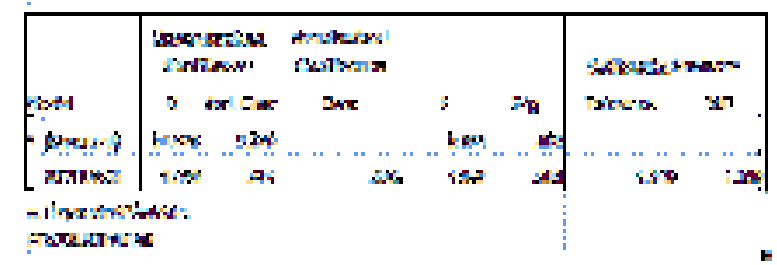

Persamaan regresi linier sederhana di atas menujukkan bahwa variabel independen atau motivasi mempengaruhi variabel dependen, hal ini dapat dilihat Sig $(0,000)<$ a $(0,05)$, hasil tersebut bermakna bahwa motivasi memiliki pengaruh terhadap produktivitas.

$Y=4,822+1,078$

Nilai konstanta sebesar 4,822 artinya tanpa adanya motivasi maka produktivitas kerja karyawan Bank Syariah Mandiri Area Palu memiliki persepsi positif. Sedangkan koefisien motivasi produk sebesar 1,078, yang menunjukkan bahwa apabila motivasi meningkat, maka dapat mempengaruhi produktivitas kerja karyawan Bank Syariah Mandiri semakin meningkat.

\subsection{Pengujian Hipotesis}

Uji Hipotesis dilakukan dengan Uji T. Uji $\mathrm{T}$ dilakukan mengetahui pengaruh antara motivasi terhadap produktivitas kerja karyawan Mandiri Syariah Mandiri Area Palu, Maka dilanjutkan Uji $\mathrm{T}$ yang dapat dilihat sebagaiberikut :
Berdasarkan hasil perhitungan statistik, maka dapat diketahui bahwa variabel tentang motivasi memiliki nilai

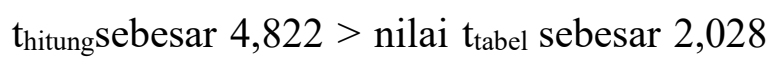
dan memiliki nilai signifikan (sig) 0,000 pada tabel coefisients dengan nilai $a$ (tingkat signifikan) 0,05 . Artinya $0,000<0,05$. Dengan nilai ini memberikan makna bahwa variabel motivasi $(\mathrm{X})$ memberikan pengaruh secara signifikan terhadap produktivitas kerja karyawan (Y). Adapun besaran pengaruhnya dapat dilihat pada kolom Beta. Besaran pengaruh varibel $\mathrm{X}$ terhadap pengaruh variabel Y yaitu 62,6\%.

\subsection{Pembahasan}

Berdasarkan hasil perhitungan statistik, maka dapat diketahui bahwa variabel tentang motivasi memiliki nilai thitung sebesar 4,822> nilai t-tabel sebesar 2,028 dan memliki nilai signifikan (sig) 0,000 pada tabel coefisients dengan nilai $a$ (tingkat signifikan) 0,05 . Artinya $0,000<0,05$. Dengan nilai ini memberikan makna bahwa variabel Motivasi (X) memberikan pengaruh secara signifikan terhadap Produktivitas kerja (Y). Adapun besaran pegaruhnya dapat dilihat pada kolom Beta. Besaran pengaruh variabel $\mathrm{X}$ terhadap variabel $\mathrm{Y}$ yaitu $62,6 \%$. Hasil ini dapat memberikan gambaran bahwa responden (Karyawan) memandang bahwa motivasi yang dimiliki oleh karyawan sudah 
mampu mempengaruhi secara signifikan untuk meningkatkan kinerja karyawan.

Menurut Akh. Muwafik dalam bukunya yang berjudul Bekerja dengan Hati Nurani,ciri-ciri motivasi yang dapat memberikan kepribadian baik dan dibenarkan oleh Islam adalah niat baik dan benar, serta takwa dalam bekerja.

Untuk sifat takwa, orang yang bertakwa atau bertanggungjawab akan selalu menampilkan sikap-sikap positif, adapun sikap-sikapnya adalah :

1. Bekerja dengan cara terbaik sebagai wujud tanggung jawab terhadap kerja dan tugas yang diamanahkan.

2. Menjauhi segala bentuk kemungkaran untuk dirinya dan orang lain dalam bekerja. Misalnya tidak malas-malasan, merugikan rekan kerja dsb.

3. Taat pada aturan

4. Hanya menginginkan hasil pekerjaan yang baik dan halal.

Hasil analisa dari 38 respondenyang dikaitkan dengan teori sifat takwa, maka dapat disimpulkan bahwa sifat takwa terdapat dalam motivasi para karyawan yang tercantum dalampernyataan yaitu, pernyataan pertama dengan rata-rata nilai $4,28 \%$, Nilai dari pernyataan pertama ini menandakan bahwa pernyataan tersebut masuk dalam kriteria sangat baik. Dimana salah satu sifat takwa adalah sikap tanggung jawab seorang muslim terhadap keimanan yang telah diikrarkannya. Sebab takwa adalah bagian dari iman. Adanya unsur iman dalam takwa dikarenakan iman adalah sumber dan dasar takwa. Iman yang benar adalah yang tidak bercampur dengan keraguan, dan melahirkan semangat untuk beramal/perbuatan baik. Perbuatan baik tidak dapat pahala kecuali dengan iman.

Pernyataan kedua dengan nilai ratarata nilai 4,39\%, Nilai pernyataan kedua ini menandakan bahwa pernyataan tersebut masuk dalam kriteria sangat baik.Jika dikorelasikan dengan sudut pandang Islam, menyelesaikan tanggung jawab agar pekerjaan selesai adalah bagian dari takwa. Orang yang bertakwa tidak membedabedakan aktivitas yang besar maupun yang kecil semua dilakukan, karena tidak ada yang luput dalam hitungan Allah. Terpatri dalam hati untuk menjauhi dosa yang kecil agar tidak menimbulkan dosa yang besar. Yang dipandangbukan kecilnya dosa yang dilakukantapi melihat keagungan Allah dan hak-hak-Nya yang akan terbaikan bila tidak dikerjakan.

Pernyataan kelima dengan rata-rata nilai 4,21\%,Nilai pernyataan kelima menandakan pernyataan tersebut masuk dalam kriteria sangat baik. Pernyataan kelima ini memuat makna tentang semangat kerja yang merupakan bagian dari ikhlas dalam bekerja, dimana ketikasemangat kerja ada maka akan menghasilkan pekerjaan yang 
baik.Islam adalah agama yang kaffah. Dalam Islam, semua persoalan hidup manusia sudah diatur dan diberikan solusi yang mengandung ajaran kebenaran. Termasuk dalam perkara-perkara yang bisa menghambat terlaksananya sebuah pekerjaan, salah satunya adalah sifat malas.Orang malas simbol orang lemah: lemah agamanya, lemah ekonominya, lemah pendidikannya, lemah tali silaturahimnya, lemah kekuasaannya. Maka ujung semua kelemahan itu adalah kemalasan seseorang untuk berusaha dan bekerja.

Pernyataan keenam dengan rata-rata nilai 4,10\%, Nilai ini menandakan bahwa pernyataan masuk dalam kriteria baik. Seperti yang sudah dijelaskan pada pernyataan sebelumnya bahwa semangat kerja adalah bagian dari Islam, dimana semangat kerja juga mampu mempengaruhi kemajuan ketika menyelesaikan pekerjaan.Energi yang dikeluarkan saat bekerja tidak hanya terfokus dan terkuras ke target atau hasil, melainkan penyempurnaan proses menjadi urgen dan keharusan. Maka inilah inti bahwa proses jauh lebih penting daripada hasil. Dari semangat kerja tersebut menghasilkan kemajuan yang bermanfaat untuk hasil pekerjaan.

Pernyatan kesepuluh dengan nilai rata-rata $4,05 \%$, Nilai ini menandakan bahwa pernyataan tersebut masuk dalam kriteria baik. Dalam Islam, tanggung jawab terhadap nasabah adalah bagian dari sifat takwa. Menurut al-Razy ${ }^{39}$ takwa dalam alQuran bermakna khasyyah (rasa takut). Seperti dalam firman Allah dalam surat anNisa ayat 1 : ياأيها الناس اتقوا رَبَّكُمُ

Maksudnya : "Wahai manusia takutlah kepada Tuhan kamu".

Dalam Jami' al-Bayan, al-Tabary (2000: 1/233) menjelaskan definisi orang bertakwa pada firman Allah hudan li almuttaqiin dalam surat Al-Baqarah ayat 2 dengan mengatakan :

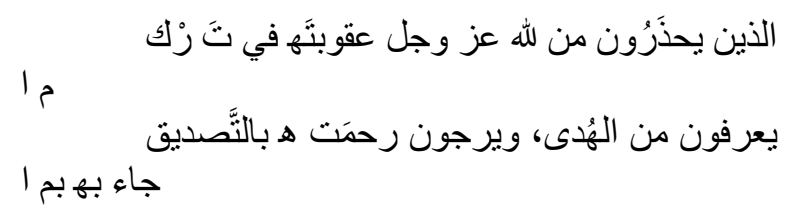

"Orang-orang yang bertakwa adalah mereka yang berhati-hati dengan balasan Allah bila meninggalkan petunjuk yang telah mereka ketahui, dan mengharapkan rahmatNya dengan meyakini apa yang diturunkanNya".

Hasil ini dapat menjadi gambaran bahwa walaupun motivasi dalam perspektif Ekonomi Islam tidak disebutkan secara spesifik, tetapi motivasi menurut perspektif Islam terdapat dalam kinerja para karyawan.

\section{KESIMPULAN}

Berdasarkan hasil analisis dan pembahasan dalam penelitian ini, maka dapat disimpulkan bahwa hasil tanggapan

${ }^{39}$ Mac Saichon, “Makna Takwa dan Urgensitasnya dalam Al-Qur'an”vol . 3 N o . 1 (Juni 2017)

http://jurnal.radenfatah.ac.id/index.php/usroh/article/d ownload/1505/1179Diakses 3 Januari 2020 
responden terhadap penilaian motivasi menunjukkan nilai bobot rata-rata sebesar 160. Berdasarkan rentang klasifikasi termasuk dalam kategori sangat baik. Hasil ini menandakan bahwa secara keseluruhan motivasi karyawan pada Bank Syariah Mandiri Area Palu sangat baik. Hasil tanggapan responden terhadap penilaian produktivitas kerja menunjukkan nilaibobot rata-rata sebesar 150. Berdasarkan rentang klasifikasi termasuk kategori baik. Hasil ini berartibahwa secara keseluruhan produktivitas kerja karyawan pada Bank Syariah Mandiri Area Palu sudah baik namun dimensi sikap mental memiliki nilai bobot di bawah bobot rata-rata variabel produktivitas kerja, yaitu pada indikator Keluhan dan meraa berat terhadap beban pekerjaan yang menjadi tanggung jawab.

Berdasarkan hasil penelitian dan pembahasan, maka dapat disimpulkan bahwa terdapat pengaruh motivasi terhadap produktivitas kerja karyawan Bank Syariah Mandiri Area Palu secara signifikandengan koefisien korelasi $\mathrm{r}=0,510$. Berdasarkan kriteria Champion dengan nilai $r=0,510$, maka hubungan ini termasuk hubungan yang cukup kuat. Berdasarkan koefisien diterminan (KD) diperoleh $\mathrm{r} 2=0,2601$; artinya pada penelitian ini motivasi memberikan peranan terhadap produktivitas kerja sebesar 26,01\%, sedangkan sisanya $73,99 \%$ dipengaruhi oleh faktor-faktor lain.
Hasil tersebut membenarkan hipotesis penelitian, yaitu terdapat pengaruh motivasi terhadap produktivitas kerja karyawan pada PT X Bandung secara signifikan. motivasi memiliki hubungan dan pengaruh secara signifikan terhadap produktivitas kerja Karyawan Bank Syariah Mandiri Area Palu, artinya semakin baik motivasi kerja pegawai maka akan memberikan produktivitas kerja yang baik pula.

\section{Daftar Pustaka}

Jusmaliani,2011,Pengelolaan Sumber Daya Insani, Jakarta: PT. Bumi Aksara

Ainal,Nur, Idayanti, Fauziah Umar. "Pengaruh Masa Kerja, Pelatihan, dan MotivasiTerhadap ProduktivitasKerjaKaryawan Pada PT. Bank SULSELBARCabang Utama Makassar". Vol 1 No.1 (April 2018) http://feb.unhas.ac.id/jurnal/index.php/ hjabe/article/view/32 Diakses 27 Mei 2019.

Mulyadi, Hari. "Pengaruh Motivasi dan Kompetensi Kerja Terhadap Produktivitas Kerja Karyawan pada PT. Galamedia Bandung Perkasa" vol. 9 No. 7 (Juli 2010) https//ejournal.upi.edu/index.php/mana jerial/article/view/1807, Diakses 21 Oktober 2019.

Kartika,IbriatiAlimuddinPengaruhMotivasiT erhadapProduktivitasKerjaKaryawanP ada PT. Telkom Indonesia, Cabang Makassar,

http://repository.unhas.ac.id/bitstream/ handle/ 123456789/2909(Diakses tanggal 25 Januari 2019)

HasibuanMalayu S.P, 2014, Manajemen Sumber Daya Manusia, Jakarta: Bumi Aksara

HasibuanMalayu S.P., 2014, Organisasi dan Motivasi,Jakarta: PT. Bumi Aksara, 
Departemen Agama Republik Indonesia, 1989, Al-qur'an dan Terjemahannya, (Semarang: CV. Alwaah,

Motivasi Kerja dalam Islam,2011, Ananto Pramadhika, Jurnal Motivasi Kerja, September

Ibriati Kartika, Pengaruh Motivasi Terhadap Produktivitas kerja Karyawan pada PT. Telkom Indonesia Cabang Makassar,

http://repository.unhas.ac.id/bitstream/ handle/123456789/2909/(Diakses tanggal 23 Januari 2019)

Rizal, Mohammad,2016, Perbankan Syariah, Malang: Empatdua Media,

Observasi Pra Penelitian (Wawancara dengan Pak Syahrullah, Petugas Bagian Gadai tanggal 15 Mei 2019)

Ainal,Nur, Idayanti, Fauziah Umar. "Pengaruh Masa Kerja, Pelatihan, dan MotivasiTerhadap ProduktivitasKerjaKaryawan Pada PT. Bank SULSELBARCabang Utama Makassar". Vol 1 No.1 2018. http://feb.unhas.ac.id/jurnal/index.php/ hjabe/article/view/32 Diakses 27 Mei 2019.

Kartika, Ibriati Alimuddin. "Pengaruh Motivasi Terhadap Produktivitas Kerja Karyawan pada PT. Telkom Indonesia, Cabang Makassar". Skripsi Makassar: Universitas Hasanuddin Makassar. 2012.

http://repository.unhas.ac.id/bitstream/ handle/123456789/skripsi\%20lengkap \%20FEB- MANAJ EMENIBRIATI\%20KARTIKA\%20ALIMU DDIN.pdf Diakses 3 Juli.

Siti Magfiroh. "Pengaruh Kepemimpinan Islami dan Motivasi Kerja Terhadap Kinerja Karyawan di Lembaga Keuangan Syari'ah KJKS Kabupaten Kendal(Studi Kasus KJKS di Kecamatan Rowosari dan Weleri)" Skripsi Semarang: IAIN Walisongo Semarang. 2012.

http://library.walisongo.ac .id/digilib/files/disk1/139/jtptiain-- sitimaghfi-6916-1-sitimag-h.pdf.

Diakses 19 Oktober 2019.

Mursi. Abdul Hamid,1999,SDM Yang Produktif, Terj. Moh Nurhakim, Jakarta: Gema Insani Pres,

Arep. Ishak dan Hendri Tanjung, 2003, Manajemen Sumber Daya Manusia, Jakarta: Universitas Trisakti,

Wibowo, 2007, Manajemen Kinerja Edisi Ketiga, Jakarta: RajaGrafindo Persada.

Hasibuan, Malayu S.P,2014,Organisasi dan Motivasi Dasar Peningkatan Produktivitas, Jakarta: Bumi Kasara,

Mangkunegara, ,A. Anwar 2004, ManajemenSumberDayaManusia Perusahaan, Bandung: RosdaKarya,

Sinungan, .Muchdarsyah2003, ProduktivitasApadanBagaimana, Jakarta: BumiAksara,

Maryani, "Motivasi dalam perspektif Islam”,http://journal.staimaarif jambi.ac.id/index. php./annadhah/article/view/42/110a (Diakses tanggal November 2019)

Misna Kablina Nur, "Pengaruh Motivasi Kerja dalam Perspektif Islam terhadap Produktivitas Kerja Karyawan Pada PT. TELKOM Makassar, http://repositori.uinalauddin.ac.id/7641/ (Diakses tanggal 10 Mei 2019)

Nurdin, N., Pettalongi, S. S., \& Yusuf, K. (2018, 27-28 Sept. 2018). Knowledge Management Model in Syariah Banking. Paper presented at the 2018 5 th International Conference on Information Technology, Computer, and Electrical Engineering (ICITACEE).

Nurdin, N., \& Yusuf, K. (2020). Knowledge management lifecycle in Islamic bank: the case of syariah banks in Indonesia. International Journal of Knowledge Management Studies, 11(1), 59-80. doi: 10.1504/ijkms.2020.105073

Saleh ,Akh. Muwafik, 2009, Bekerja dengan Hati Nurani, Jakarta: Erlangga, 
Alaik Allama, "Pengaruh Motivasi Kerja Islam dan Budaya Kerja Islam Terhadap Produktivitas Kerja Karyawan BAITUL MAL WAT TAMWIL (BMT) DI KUDUS, http://library.walisongo.ac.id/digilib/fil es/disk1/136/jtptiain--alaikallam

(Diakse tanggal 10 Mei 2019)

Suhartini ,Eka, 2013, Motivasi, KepuasanKerja Dan Kinerja, Jakarta: Alauddin University Press,.

Hasibuan. Malayu S.P, 2014, Organisasi dan Motivasi Dasar Peningkatan Produktivitas,Jakarta: PT Bumi Kasara Syahyuti, Hasibuan, 2010. Devinisi, Variabel, Indikator dan Pengukuran dalam Ilmu Sosial, Jakarta: Bina Rena Pariwara

Sinungan , Muchdaryah, 1997, Produktivitas apa dan Bagaimana, Jakarta: Bumi Aksara.

Moekijat,1989,Manajemen Kepegawaian, Bandung: Mandar Maju

Badriyah. Mila, 2015, Manajemen Sumber Daya Manusia, Bandung: Pustaka Setia

Sutrisno . Edy, 2014Manajemen Sumber Daya Manusia, Jakarta: Prenada Media Group

Margono, 2004, MetodePenelitian Pendidikan, Jakarta: PT.RenekaCipta ,

Ardianto. Elvinaro, 2011, Metodologi Penelitian untuk Public Relations Kuantitatif dan Kualitatif, Bandung: Simbiosa Rekatama Media

Bungin . M Burhan, , 2005, Metodologi Penelitian Kuantitatif, Jakarta: Kencana Prenada Media Group

Rochaety,Ety, dkk, 2007, Metode Penelitian Bisnis Dengan Aplikasi SPSS, Jakarta: Mitra Wacana Media,

Observasi Pra Penelitian (Wawancara dengan Pak Adrianto, Petugas Bagian Gadai tanggal 03 April 2019)
Martono, Nanang, 2012, Metode Penelitian Kuantitatif, Cet 3: Jakarta: PT. Raja Grafindo Persada,

Siregar. Syofian, 2010.Statistika Deskriptif untuk Penelitian, PT. RajaGrafindo Persada,

Suryabarata .Sumardi, 2010, Metodologi Penelitian, Jakarta: PT. Grafindo Persada,

Sugiyono, 2011, Metode Penelitian Kuantitatif, Kualitatif dan $R \& D$,(Bandung: CV. Alvabeta,

Sulaiman,2010,AnalisisRegresiMenggunaka $n$ SPSS: ContohKasusdanPemecahannya Yogya karta: Andi,

Bank Syariah Mandiri, Annual Report, diakses 12 juli 2019.

Nurung. Ismail Daeng, Wawancara Bank Syariah MandiriProvinsi Sulawesi Tengah CabangPalu. 12 Juli 2019.

Yogi Iskandar, "Pengaruh Kesesuaian Kompensasi terhadap Kinerja Karyawan PT. Bentoel Distribusi Cabang Utama Palu”, (Skripsi IAIN Palu), 54

Mac Saichon, "Makna Takwa dan Urgensitasnya dalam Al-Qur'an” vol . $3 \mathrm{~N} \quad \mathrm{o} \quad$. 1 (Juni 2017) http://jurnal.radenfatah.ac.id/index.php /usroh/article/download/1505/1179 Diakses 3 Januari 2020 